Vol. 4 No. 4 (Jun 2018) 350-359

\title{
ANALISIS STRATEGI BERSAING INDUSTRI MAKANAN TRADISIONAL KHAS SUMATERA BARAT
}

\author{
Oleh : \\ Yossi Indrawati Syuhardi \\ Program Studi Teknik Informatika \\ Fakultas Teknik, Matematika dan Ilmu Pengetahuan Alam \\ Universitas Indraprasta PGRI Jakarta \\ E-mail : yossiindrawatisyuhardi@gmail.com
}

\begin{abstract}
ABSTRAK
Usaha Kecil dan Menengah (UKM) memiliki peranan dalam pembangunan ekonomi nasional. UKM mengalami pertumbuhan setiap tahunnya. Hal ini bisa dilihat dari laju perkembangan UKM yang cenderung meningkat dalam beberapa tahun terakhir. Studi literature ini bertujuan untuk mengetahui strategi bersaing yang terjadi pada UKM makanan tradisional khas Sumatera Barat yaitu Keripik Balado Mahkota Asli yang mempengaruhi faktor internal maupun eksternalnya. Dalam penelitian ini digunakan adalah data sekunder, Data sekunder diperoleh dari laporan tertulis perusahaan atau dokumen perusahaan dan dari artikel atau literatur yang terkait dengan penelitian ini yakni data dari Biro Pusat Statistik (BPS). Hasil Penelitian ini dimana Dinas Koperasi dan usaha kecil menyediakan akses pembiayaan bagi KUMKM melalui pola dana bergulir yang bertujuan untuk memberikan layanan pembiayaan secara mandiri bagi KUMKM yang belum memenuhi kriteria kelayakan perbankan umum. Selain itu juga melakukan program pemotongan hutang (haircut) bagi UMKM yang bertujuan membantu UMKM yang terjerat hutang agar bisa kembali membangun usahanya.
\end{abstract}

Kata kunci : Analisis stategi, Industri kecil, Makanan tradisional.

\section{A. PENDAHULUAN}

Perkembangan industri kecil dan menengah mendapat tantangan yang semakin besar akibat semakin kuatnya globalisasi. Disinilah peran penting dari usaha kecil dan menengah (UKM) dalam meningkatkan perekonomian nasional karena mampu menciptakan lapangan kerja bagi suatu Negara. Usaha kecil dan menengah juga berperan dalam pembangunan ekonomi nasional dan mendistribusikan hasil-hasil pembangunan serta merupakan motor penggerak pertumbuhan aktifitas ekonomi nasional. Dalam krisis ekonomi yang terjadi di Indonesia pada tahun 1997, dimana terjadi ketimpangan dan ketidakstabilan perekonomian Indonesia. Berdasarkan data BPS di Indonesia dari tahun 1997 sampai pada tahun 1998 menunjukkan sektor UKM dapat bertahan dan terbukti menghadapi krisis (Jafar, 2004) Menurut data BPS tahun 
2003, jumlah UKM di Indonesia adalah 42 juta unit atau 99,99 persen dari jumlah seluruh unit usaha di Indonesia. Sebanyak 99,85 persen terdiri dari skala usaha kecil dan 0,14 persen dari skala usaha menengah.

Sebagian besar usaha di Indonesia berada pada skala usaha kecil dan menengah. Berdasarkan data dari situs resmi Propinsi Sumatera Barat (2013) terdapat industri kecil dan menengah yang ada di Sumatera Barat. Jumlah industri pada tahun 2012 sebanyak 47.819 unit terdiri dari industri kecil 47.585 unit dan industri menengah sebesar 208 unit.

Berbagai usaha dari berbagai sektor mewarnai perekonomian di Provinsi Sumatera Barat, salah satunya adalah makanan. Maknan merupakan sektor dengan jenis dan unit terbanyak yang berada di Sumatera Barat. Berbicara tentang makanan, Provinsi Sumatera Barat merupakan daerah yang kaya akan makanan khasnya.

Setiap daearah di Provinsi Sumatera Barat ini umumnya memiliki makanan khas tersendiri sehingga membuat identitas tersendiri bagi masing-masing daerah. Contohnya untuk kota Batusangkar terkenal dengan makanan khasnya yaitu dakakdakak, Kota Payakumbuh terkenal dengan makanan khasnya kalamai dan berbagai makanan khas daerah lain yang berada di Sumatera Barat. Barbagai makanan khas daerah tersebar diseluruh daerah Sumatera Barat, termasuk kota Padang.

Untuk kota Padang sendiri sudah banyak terdapat UKM yang menawarkan makanan khas daerah beberapa diantaranya sudah cukup terkenal seperti keripik balado Sherley, Christine Hakim dan Mahkota. Ketiga UKM ini telah berkontribusi dalam peningkatan perekonomian dikota Padang. UKM tersebut adalah UKM yang banyak bergerak dibidang pengolahan dan pendistribusian makanan tradisional atau makanan khan daerah (Riaswati,2004) Keripik Balado Mahkota asli merupakan industri kecil makanan trasional yang menjual jajanan ringan dan oleh-oleh khas minang yang berdiri sejak tahun 1993, pabrik keripik balado mahkota asli berlokasi dikawasan Dadok Tunggul Hitam. Saat ini keripik balado Mahkota Asli sudah berkembang pesat, telah membuat makanan ringan sejenis hingga puluhan item. Diantaranya keripik balado, sanjai, cinsang keripik, jagung goring, emping jagung, kipang kacang, karak kaliang, ampere, kacang-kacang, rakik maco, randang paru, randang telor dan lain-lain.

Dalam menjalankan usaha industri makanan tradisional Keripik Mahkota Asli mengalami persaingan yang cukup ketat dengan industri sejenisnya, terutama industri sejenis yang berskala mikro dan kecil. Hal ini ditunjukan dengan pendapatan Keripik Balado Mahkota Asli yang berfluktuatif. Pesaing Keripik Balado Mahkota Asli adalah sherley, Christine Hakim, Rohana Kudus, Oma, 4 x 6 serta sejumlah industri makanan tradisional lain di kota Padang yang belum memiliki merk dagang. Usahauasaha tersebut dikategorikan sebagai pesaing utama Keripik balado mahkota Asli karena memproduksi produk yang relatif sama dalam skala usaha yang hampir sama. Menurut Pearce dan Robinson (1997), industri membutuhkan strategi yang sesuai dengan kondisi industri untuk dapat bertahan di pasar, dapat menghadapi persaingan, ancaman dan peluang pasar.

Dalam memformulasikan trategi yang tepat, industri harus dapat mengevaluasi 


\section{Y. I. Syuhardi / Journal of Applied Business and Economics \\ Vol. 4 No. 4 (Jun 2018) 350-359}

kekuatan dan kelemahan lingkungan internalnya dan mengidentifikasi peluang dan ancaman yang datang dari lingkungan eksternal industri itu. Strategi yang paling tepat bagi suatu industri kecil adalah strategi yang disusun dengan mempertimbangkan kondisi industri yang terdiri dari kekuatan dan kelemahan untuk memanfaatkan peluang dan mengantisipasi ancaman yang ada dalam lingkungan yang selalu berubah dan semakin kompetitif (David, 2004). Keripik Balado Mahkota Asli harus mengetahui kekuatan dan kelemahannya dibandingkan dengan pesaing-pesaing utamanya. Keripik Balado Mahkota Asli juga harus mengetahui kekuatan dan kelemahan utama pesaingnya sehingga dapat merumuskan keunggulan bersaing relative terhadap pesaing-pesaingnya untuk merebut pangsa pasar.

Adapun tujuan dari penulisan ini adalah : (1) Melakukan identifikasi factor eksternal peluang dan ancaman yang mempengaruhi posisi persaingan keripik Balado Mahkota Asli; (2) Malakukan identifikasi faktor eksternal kekuatan dan kelemahan yang mempengaruhi posisi pesaing Keripik Balado Mahkota Asli; (3) mengetahui posisi bersaing Keripik Balodo Mahkota Asli bila dibandingkan denga pesaing utamanya; (4) Menentukan alternative strategi yang dapat dipilih oleh Keripik Baldo Mahkota Asli untuk menjalankan usahanya.

\section{B. TINJAUAN PUSTAKA Definisi Usaha Kecil Menengah (UKM)}

Usaha Kecil merupakan istilah yang sering kita dengar dan baca diberbagai media masa. Akan tetapi sedikit orang yang tahu kriteria peluang usaha yang dikategorikan sebagai UKM. Menurut Undang-Undang nomor 20 tahun 2008 UKM memliki kriteria sebagai berikut : (1). Usaha Mikro yaitu usaha produktif milik orang perorangan atau badan usaha milik perorangan yang memenuhi kriteria yaitu mimiliki kekayaan bersih paling banyak 50.000.000 rupiah tidak termasuk tanah dan bangunan, dan memiliki penjualan tahunan paling banyak 300.000.000 rupuah. (2) Usaha kecil yaitu usaha ekonomi produktif yang berdiri sendiri yang dilakukan oleh orang perorangan atau badan usaha yang bukan merupakan anak perusahaan atau bukan cabang perusahaan yang dimiliki, dikuasai atau menjadi bagian baik langsung maupun tidak langsungdari usaha menengah atau usaha besar yang memenuhi kriteria yaitu memiliki kekayaan bersih dari 50.000.000 rupiah dan paling banyak 500.000.000 rupiah. Penjualan pertahunnya lebih dari 300.000.000 rupiah sampai 2.500.000.000 rupiah. (3).Usaha menengah yaitu kegitan usaha yang didirikan berdasarkan dari inisiatif seseorang, yang dilakukan oleh orang perorangan atau badan usaha yang bukan merupakan anak perusahaan atau cabang perusahaan yang dimiliki, dikuasai, atau menjadi bagian langsung maupun tidak langsung dengan usaha kecil atau usaha besar, yang memenuhi kriteria memiliki kekayaan lebih dari 500.000.000 rupiah sampai 10.000.000.000 memiliki hasil penjualan pertahun lebih dari 2.500.000.000 rupiah sampai 50.000.000.000 rupiah.

Menurut BPS (2004), memberikan defenisi UMKM berdasarkan kuantitas tenaga kerja. Usaha kecil merupakan usaha yang memiliki jumlah tenaga kerja 7 
orang sampai dengan 20 orang, sedangkan usaha menengah merupakan usaha yang memiliki jumlah tenaga kerja 20 orang sampai dengan 99 orang.

\section{Peranan Industri Kecil}

Kecil Industrialisasi dalam suatu tahap pembangunan dianggap sebagai suatu symbol kemajuan san kesuksesan pembangunan disuatu negara. Selain itu, industrialisasi dianggap sebagai kunci yang dapat membawa masyarakat kearah kemakmuran, serta dapat mengatasi masalah lapangan kerja yang semakin menyempit pada sektor pertanian ( Akmal, 2006) Menurut Sriyana (2007:47), Perkembangan sektor UKM yang pesat tercermin dari kontribusi mereka dalam berbagai indicator ekonomi yaitu perannya dalam peningkatan PDB, jumlah unit usaha yang terbentuk, dan dalam penyerapan tenaga kerja

\section{Makanan Tradisional}

Makanan Tradisional atau khas adalah makanan dan minuman yang biasa dikonsumsi oleh masyarakat tertentu, dengan citaras khas yang diterima oleh masyarakat tersebut. Makanan tradisional adalah makanan yang termasuk jajanan serta bahan campuran yang digunakan secara tradisional dan telah lama berkembang secara spesifik di daerah atau masyarakat Indonesia.

Pada umumnya makanan tradisional diolah dari dulu yang sudah dikenal masyarakat setempat dengan bahan-bahan yang diperoleh dari sumber local yang memiliki cita rasa yang relative sesuai dengan selera masyarakat setempat (Prasetya, 2007

\section{Manajemen Strategi}

Manajemen strategi menurut David (2004) adalah seni dan pengetahuan untuk merumuskan, mengimplementasikan dan mengevaluasi keputusan lintas fungsional yang membuat perusahaan mampu mencapai objektifnya. Fokus manajemen strategi terletak pada memadukan manajemen, pemasaran, Keuangan atau akuntansi, produksi-operasi penelitian dan pengembangan serta system informasi computer untuk mencapai keberhasilan suatu organisasi. David (2004) mengemukankan bahwa bahwa terdapat empat strategi dasar yang dapat diterapkan perusahaan. Strategi itu adalah strategi integrasi, strategi intensif, strategi diversifikasi dan strategi defensif.

Strategi integrasi dapat dibagi menjadi tiga strategi yaitu integrasi ke depan, ke belakang, dan horizontal. Integrasi ke depan diartikan sebagai memperoleh kepemilikan atau meningkatkan kendali atas distributor atau pengecer. Integrasi ke belakang berarti mencari kepemilikan atas perusahaan pemasok. Sedangkan integrasi horizontal didefenisikan sebagai mencari kepemilikan atau meningkatkan kendali atas pesaing. Strategi intensif yang dirujuk oleh David (2004) adalah penetrasi pasar, pengembangan pasar, dan pengembangan produk. Penetrasi pasar diartikan sebagai mencari pangsa pasar yang lebih besar untuk produk atau jasa yang sudah ada sekarang lewat pemasaran yang lebih gencar. Pengembangan pasar berusaha memperkenalkan produk dan jasa yang ada ke wilayah geografi baru. Pengembangan 


\section{Y. I. Syuhardi / Journal of Applied Business and Economics \\ Vol. 4 No. 4 (Jun 2018) 350-359}

produk berarti mencari kenaikan penjualan dengan memperbaiki produk atau jasa yang sudah ada atau mengembangkan yang baru. Strategi diversifikasi dapat dibagi menjadi tiga yaitu diversifikasi konsentrik yang berarti menambah produk atau jasa baru tetapi berkaitan.

Kemudian diversifikasi konglomerat yang diartikan sebagai menambah hasil produk atau jasa baru, tidak berkaitan dan terakhir diversifikasi horizontal yang berarti menambah produk atau jasa baru, tidak berkaitan untuk pelanggan yang ada (David, 2004). Strategi generik terakhir yang dikemukakan David (2004) adalah strategi defensif yang terdiri atas usaha patungan, penghematan atau penciutan, divestasi dan likuidasi. Usaha patungan didefenisikan sebagai dua perusahaan sponsor

\section{METODE PENELITIAN}

Penelitian ini dilakukan di Keripik Balado Mahkota Asli yang berlokasi dikawasan Dadok Tunggul hitam, Kota Padang Provinsi Sumatera Barat. Pemilihan tempat ini dilakukan secara sengaja (purposive) dengan pertimbangan bahwa Keripik Balado Mahkota Asli merupakan salah satu industri kecil yang bergerak di bidang pengolahan dan pemasaran makanan tradisional khas Kota Padang. Data yang digunakan dalam penelitian ini adalah data sekunder.

Data sekunder diperoleh dari laporan tertulis perusahaan atau dokumen perusahaan dan dari artikel atau literatur yang terkait dengan penelitian ini yakni data dari Biro Pusat Statistik (BPS) dan artikel di perpustakaan lingkungan IP

Tabel kebutuhan Data Sekunder

\begin{tabular}{|c|c|c|c|}
\hline No & Item & Sumber & $\begin{array}{l}\text { Metode } \\
\text { Pengumpulan Data }\end{array}$ \\
\hline 1. & $\begin{array}{l}\text { Data-data lingkungan industri } \\
\text { makanan tradisional khas Kota } \\
\text { Padang }\end{array}$ & $\begin{array}{l}\text { BPS, Pemda Kota } \\
\text { Padang, Internet, } \\
\text { Perpustakaan IPB, } \\
\text { dan artikel terkait. }\end{array}$ & $\begin{array}{l}\text { Pengumpulan data } \\
\text { sekunder dilakukan } \\
\text { dengan metode } \\
\text { pengumpulan }\end{array}$ \\
\hline 2 & $\begin{array}{l}\text { Gambaran Umum dan laporan } \\
\text { aktivitas fungsional perusahaan } \\
\text { Data SDM Perusahaan }\end{array}$ & $\begin{array}{l}\text { Sekretaris Keripik } \\
\text { Balado Mahkota Asli } \\
\text { Sekretaris Keripik } \\
\text { Balado Mahkota Asli }\end{array}$ & $\begin{array}{lr}\text { langsung } & \text { dengan } \\
\text { mendatangi } & \text { pihak- } \\
\text { pihak } & \text { yang } \\
\text { memiliki } & \end{array}$ \\
\hline 3 & $\begin{array}{l}\text { Struktur biaya dan } \\
\text { finansial Perusahaan }\end{array}$ & $\begin{array}{l}\text { Bendahara Keripik } \\
\text { Balado Mahkota Asli }\end{array}$ & $\begin{array}{l}\text { akses terhadap data } \\
\text { yang dibutuhkan }\end{array}$ \\
\hline
\end{tabular}

\section{Metode Pengolahan dan Analisis Data}

Data Pada penelitian ini dilakukan metode pengolahan dan analisis data melalui pendekatan manajemen strategis. Analisis data dilakukan secara kualitatif dan kuantitatif. Hasil pengolahan data disajikan dalam bentuk tabel, bagan dan uraian.

Analisis deskriptif digunakan untuk mendapatkan gambaran menyeluruh yang mendalam mengenai objek penelitian, sehingga dari pengamatan ini dapat diketahui 
kondisi eksternal dan internal perusahan. Hasil analisis ini disajikan dalam bentuk tabel, gambar, maupun matriks sesuai dengan hasil yang diperoleh.

\section{HASIL DAN PEMBAHASAN}

Dinas Koperasi dan usaha kecil menyediakan akses pembiayaan bagi KUMKM melalui pola dana bergulir yang bertujuan untuk memberikan layanan pembiayaan secara mandiri bagi KUMKM yang belum memenuhi kriteria kelayakan perbankan umum. Dana bergulir dikelola secara profesional dengan mengedepankan kepentingan pelayanan Koperasi, Usaha Mikro, Kecil Dan Menengah (KUMKM) secara transparan, akuntabel, produktif, efisien dan efektif.

Selain meluncurkan program dana bergilir UMKM, Kementrian Koperasi dan UKM juga melakukan program pemotongan hutang (haircut) bagi UMKM yang bertujuan membantu UMKM yang terjerat hutang agar bisa kembali membangun usahanya. Dana haircut ditujukan bagi UMKM yang memiliki kredit macet 5 miliar rupiah ke bawah. Dalam pelaksanaannya, UKM dapat mengajukan pinjaman ke bank pemerintah yang sudah menjalin kerjasama dengan Asuransi Kerugian Indonesia (Askrindo), sehingga pemilik UKM tidak perlu memiliki penjaminan (colateral).

Program haircut juga bisa berupa write off, seperti penghapusan hutang pemilik UKM di bank atau pemotongan berupa bunga atau pengurangan hutang. Melalui kebijakan ini, pemilik usaha memiliki kesempatan dan peluang untuk mendapat pinjaman dari Bank untuk memajukan usahanya

\section{Dukungan Instansi Pemerintah Propinsi Sumatera Barat}

Pemerintah daerah Propinsi Sumatera Barat memberikan perhatian khusus terhadap pembinaan dan pengembangan UKM untuk menggali dan mengoptimalisasikan keunggulan daerah. Diantaranya adalah dengan memperkuat infrastruktur usaha kecil dalam bidang pemasaran, produksi, pengadaan barang dan jasa, serta pembiayaannya, mengembangkan pusat-pusat produksi usaha kecil dan menengah yang terkait dengan fungsi marketting mix (Product, Place, Price, dan Promotion) terutama yang berada pada tingkat pemerintahan nagari (tingkat kecamatan dan tingkat kotamadya).

Potensi sumber kekayaan alam/sumber daya alam diolah melalui UKM dikelola melalui institusi pemerintahan melalui PIER (Pusat Informasi Ekonomi Rakyat) yang dikemas sebagai pusat data dan informasi ekonomi rakyat, pengembangan produk dan jasa, pemasaran dan promosi (ekspor), pembinaan SDM dan kegiatan-kegiatan lainnya yang memberikan manfaat bagi stakeholder UKM di Sumatera Barat. PIER dapat membantu kemajuan usaha kecil secara bergantian di berbagai kabupaten dan kotamadya di Sumatera Barat melalui pameran-pameran maupun kegiatan promosi produk dan jasa lainnya. Di samping terbentuknya PIER di masing-masing kenagarian, pemerintah daerah Propinsi Sumatera Barat juga melakukan upaya pengembangan pasar regional UKM (Riau, Jambi, dan Kepulauan Riau), nasional (Jakarta), dan internasional (Singapura, Malaysia, Brunei Darusslam, negara-negara 


\section{Y. I. Syuhardi / Journal of Applied Business and Economics \\ Vol. 4 No. 4 (Jun 2018) 350-359}

ASEAN lainnya) dengan mengembangkan pemasaran produk dan jasa potensial, seperti jenis produk dan komoditas, kemampuan supply, kualitas, kemasan, pengiriman tepat waktu, dan pendanaan perdagangan.

Pemerintah daerah Sumatera Barat juga melakukan penetrasi pasar global (ekspor) UKM secara terintegrasi baik di tingkat propinsi, kabupaten dan kota maupun melalui peran serta Perguruan Tinggi dan lembaga-lembaga sosial ekonomi masyarakat, tokoh ninik mamak, alim ulama, dan dukungan dari lembaga perbankan daerah. Pada beberapa UKM handicraft, pemerintah Kota Padang dan Propinsi Sumatera Barat juga menjalin kerjasama untuk menarik investor-investor yang berminat untuk menanamkan modalnya untuk pengembangan UKM, seperti: kerjasama dengan perantauperantau sukses suku Minangkabau. UKM di bidang makanan tradisional khas Kota Padang memberikan kontribusi yang besar terhadap sumbangan Pendapatan Derah Kota Padang. Oleh karena itu, pemerintah Kota Padang memberikan perhatian khusus terhadap pengembangan dan pembinaan UKMUKM tersebut.

Deperindag Kota Padang melakukan pembinaan kewirausahaan (entrepreneurship) secara berskala yang dilakukan setiap bulan di Kota Padang. Pembinaan ini mencakup pembinaan untuk memulai usaha, menjalankan usaha, dan mengembangkan usaha. Deperindag secara rutin memberikan penyuluhan tentang pencatatan dan rekapitulasi keuangan UKM serta pembinaan pelabelan dan kemasan produk. Di samping itu, pemerintah Kota Padang dan Propinsi Sumatera Barat juga berfungsi sebagai fasilitator mesin-mesin produksi modern makanan tradisional khas Kota Padang.

Di samping itu, Deperindag Kota Padang juga menyalurkan bantuan modal dan bantuan promosi produk-produk UKM khususnya UKM yang bergerak di bidang pengolahan dan pemasaran makanan tradisional khas Kota Padang. Dalam hal bantuan modal, Deperindag berperan aktif untuk menyalurkan dana bergulir dan dana MAP (Modal Awal Pendanan) dari Kementrian Koperasi dan UKM maupun danadana dari pemerintah daerah Sumatera Barat seperti IKSP dan IWAPI.

Dalam hal promosi, Deperindag melakukan kerjasama dengan berbagai instansi pemerintah lainnya baik di tingkat daerah maupun di tingkat nasional. Promosi tersebut dilakukan melalui pameran-pameran dan bazar-bazar produk khas daerah. Seperti: pameran pasar rakyat menyambut hari-hari besar di tingkat Kota Padang, pameran PKM (Pengusaha industri Kecil dan Menengah), bazar sentra makanan khas dan handicaraft, pameran padang fair di tingkat Propinsi Sumatera Barat dan berbagai pameran-pameran dan kegiatan promosi lainnya yang dilaksanakan oleh Dinas Perindustrian dan Perdagangan RI yang berskala nasional. Dukungan ini merupakan peluang UKM untuk mengembangkan dan memajukan usahanya

\section{Inflasi Menurunkan Daya Beli}

Inflasi dapat membahayakan perekonomian karena menurunkan nilai uang yang dipegang masyarakat sehingga menurunkan daya beli masyarakat. Pendapatan berkurang dapat berdampak pada turunnya pengeluaran untuk konsumsi makanan- 
makanan jenis tertentu sehingga akan membawa ancaman bagi industri yang bergerak di bidang pengolahan dan pemasaran makanan tradisional khas daerah

Tabel 2 :

sumbangan kelompok pengeluaran pada inflasi nasional Desember 2015

\begin{tabular}{ll}
\hline Kelompok Pengeluaran & Andil Inflasi (Persen) \\
\hline Umum & 3,35 \\
1. Bahan Makanan & 4,93 \\
2. Makanan jadi, Minuman, rokok dan & 6,42 \\
& Tembakau \\
3. Perumahan, air, listrik, gas dan bahan & 3,34 \\
& \\
4. Sakar & 3,43 \\
5. kesehatan & 5,32 \\
6. pendidikan, rekreasi dan olahraga & 3,97 \\
7. transport, komunikasi dan jasa keuangan & $-1,53$
\end{tabular}

\section{Sumber: Badan Pusat Statistik, 2015}

Berdasarkan data di atas dapat dilihat bahwa pada bulan Desember 2015 terjadi inflasi 3,35 persen. Inflasi terjadi karena kenaikan harga yang ditunjukkan oleh kenaikan indeks pada semua kelompok barang dan jasa dimana inflasi terbesar terjadi pada kelompok makanan

\section{E. SIMPULAN}

Simpulan yang dihasilkan dari analisis adalah sebagai berikut:

1. Keripik Balodo Mahkota Asli dipengaruhi oleh lingkungan eksternal yang menghasilkan peluang dan ancaman. Faktor-faktor eksternal yang menjadi peluang Keripik Balado Mahkota Asli adalah: (1) Dukungan Dinas Koperasi dan UKM, (2) Dukungan instansi pemerintah Propinsi Sumatera Barat (3) Peningkatan permintaan pada hari-hari besar dan libur nasional, (4) Pasar pelanggan yang tinggi, serta (5) Inovasi produk, kemasan, dan mesin-mesin industri. Faktor-faktor eksternal yang menjadi ancaman Keripik Balado Mahkota adalah: (1) Substitusi semakin banyak dan dikenal masyarakat, (2) Fluktuasi harga bahan baku, (3) Tingkat persaingan yang tinggi, (4) Industri mudah dimasuki pendatang baru, (5) Inflasi yang menurunkan daya beli.

2. Fator internal menghasilkan sejumlah kekuatan dan kelemahan Keripik Balado 


\section{Y. I. Syuhardi / Journal of Applied Business and Economics}

Vol. 4 No. 4 (Jun 2018) 350-359

Mahkota Asli. Faktor-faktor internal yang menjadi kekuatan Keripik Balado Mahkota Asli adalah: (1) Harga produk yang bersaing, (2) Produk olahan yang beragam, berkualitas, dan kontinyu, (3) Hubungan yang baik dengan berbagai instansi pemerintah, (4) Produksi dapat dilakukan setiap saat, dan (5) Loyalitas karyawan tinggi. Sedangkan faktor-faktor internal yang menjadi kelemahan Keripik Balado Mahkota Asli yaitu: (1) Daerah pemasaran masih terbatas, (2) Menggunakan modal dari luar (Bank) yang cukup besar, (3) Pencatatan keuangan masih sederhana, (4) Manajemen yang masih sederhana, dan (5) Teknologi yang digunakan masih tradisional

\section{DAFTAR PUSTAKA}

Akmal S,Yori, 2006. Analisis Faktor-Faktor yang Mempengaruhi Produktivitas Tenaga Kerja Industri Kecil Kerupuk Sanjai Di Kota Bukittinggi. Skripsi Jurusan Ilmu-ilmu Sosial Ekonomi Pertanian Fakultas Pertanian. Institut Pertanian Bogor, Bogor.

Badan Pusat Statistik 2003, Statistik Industri Besar dan Kecil. BPS, Jakarta.

Badan Pusat Statistik 2004, Statistik Industri Besar dan Kecil. BPS, Jakarta.

Badan Pusat Statistik 2006, Statistik Industri Besar dan Kecil. BPS, Jakarta.

Badan Pusat Stattstik 2015, Statistik Industri Besar dan Kecil. BPS, Jakarta.

David, R. F. 2002, Manajemen Strategi Konsep terjemahan edisi ketujuh prenhalindo, Jakarta

David, R.F. 2004 Manajemen Strategi Konsep Terjemahan edisi kesembilan, Prehalindo, Jakarta.

Jafar, H.M 2004, Upaya Pengembangan Usaha Kecil dan Menengah (UKM) dalam infokap nomor 25 tahun XX. www.smecda.com

Prasetya, B.P 2007. Analisis Strategi Promosi Makanan Tradisional Khas Kota Bogor, Gepuk dan Ikan Balita Kuruhun Pada PT. Anofood Prima Nusantara. Skripsi Jurusan Ilmu-Ilmu Sosial Ekonomi Pertanian. Fakultas Pertanian, Institut Pertanian Bogor, Bogor.

Pearce, J. A. Dan Robinson, R. B. 1997. Strategic Management: Formulation, Implementation, and Control. Sixth Edition. IRWIN. USA. 
Riaswati A. W 2004, Analisis Strategi Pemasaran Makanan Tradisional Gepuk dan Ikan Balita Khas Bogor Merek Kuruhun pada PT Intrafood Citarasa Nusantara Bogor Jawa Barat, skripsi Jurusan Ilmu-ilmu social Ekonomi Pertanian, Fakultas Pertanian Boogor, Bogor.

Sriyana, Jaka. 2007. Transformasi UKM dalam Database Alokasi Air Balai Progo Opak Oyo Dinas KIMPRASWIL ( saluran Mataram) Ver. 5.0.2 Situs resmi Provinsi Sumatera Barat. 